\title{
Technológia és kiber-utópianizmus
}

A kiber-utópianizmus diskurzusa az utópianizmus, a technológiai determinizmus, a szociális konstruktivizmus és a politikai gazdaságtan(-kritika) dialektikus kölcsönhatásai mentén jött létre. E teóriák jellemzői - lett légyen szó erősségekről, hagyatékról, vagy gyengeségekről - kiindulópontul szolgálhatnak a kibertér tulajdonságainak a történelmi előzmények tágabb kontextusában történő megvitatásához.

Kulcsszavak: internet, technológia, információs társadalom, utópianizmus, technológiai determinizmus, szociális konstruktivizmus, politikai gazdaságtan-kritika

\section{Szerzői információ:}

Iványi Márton arab filológus és újmédia kutató 2010-ben végzett az Eötvös Loránd Tudományegyetem Bölcsészettudományi Karának arab-kommunikáció szakpárján. 2011-ben a Budapesti Kommunikációs Fớiskolán politikai kommunikációs elemzố posztgraduális képesítést szerzett. 2012 óta a Budapesti Corvinus Egyetem Társadalmi Kommunikáció Doktori Iskolájának végzốs PhD-hallgatója, kutatási témája a közösségi média vélt vagy valós katalizátori szerepe a társadalmi mozgalmakban. A szóban forgó témában megjelent, fóbb publikációi: A közösségi média és a társadalmi mozgalmak (Iskolakultúra, 2014. február); Világrendszer és világháló. Facebook-forradalom, mint orientalista belelátás? (Jel-Kép, 2014/4. szám); Közösségi média: a nyilvánosság elektronikus agorája vagy posztmodern panoptikum? (Médiakutató, 2014. nyár); Megtévesztés, színlelt attitúd és a közösségi média (Médiakutató, 2015. nyár)

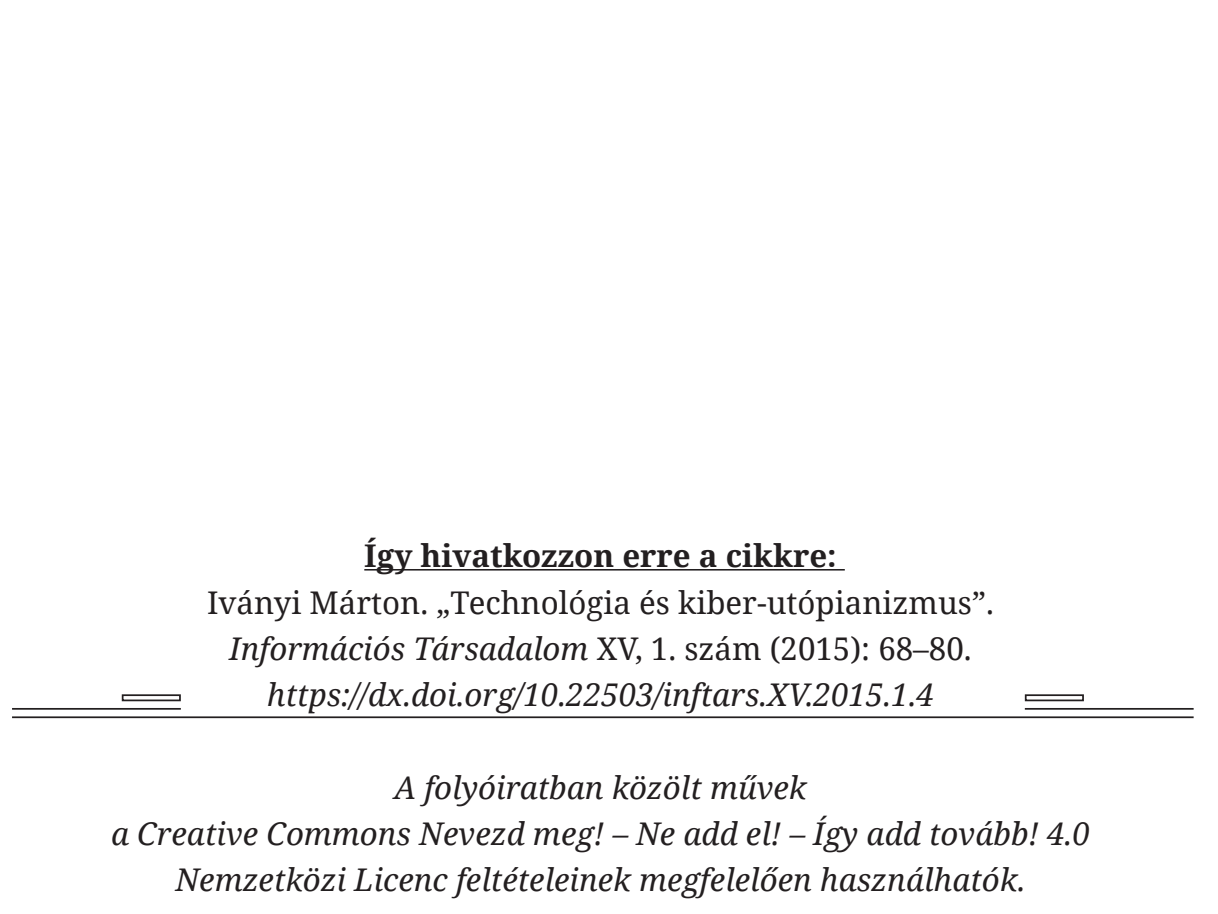




\section{Iványi Márton}

\section{Technológia és kiber-utópianizmus}

\section{A kiber-utópianizmus modernista gyökerei}

Az emberi közösségek a kibertér ${ }^{1}$ és a virtuális világok megjelenését megelózốen is az elmúlt évszázadokban egy másik, szintén ember teremtette jelenséggel néztek szembe, amelyet a továbbiakban egyszerúen technológiának nevezünk.

Nem túlzás azt állítani, hogy e több dimenziós tudásbázis érdeklődési területünk szempontjából erôteljes precedenst képez, következóleg indokolt lehet jelen szerkezeti egység figyelmének középpontjába állítani azon modern és posztmodern elméleti perspektívákat, melyek megkísérlik meghatározni a technológia és a társadalom viszonyrendszerét.

Szárnyra kapván a felvilágosodás szellemi áramlatai nyomán és az ipari forradalom tapasztalatainak hátszelével, az egymásba fonódó modernista elméleti felfogások és fejtegetések hihetetlenül „önellátó,” mindenre magyarázatot adó és következetes, tudományos és közéleti álláspontok színében, megkérdôjelezhetetlen érvényú modellekként túnnek föl. Az ezeket párbajra hívó és árnyaló posztmodern elképzelésekig, hosszú idốn keresztül egyes elvont gondolatrendszerek csak annyiban bontakozhattak ki, amennyiben egy tóról fakadtak, vagy legalábbis állandó párbeszédet folytattak a modernizmus filozófiai mozgalmával, ezzel az eszmei „magmával,” ahonnan a nézetek kiindulnak, és fejlődési pályájukra lépnek.

A modernitás elméleti klímáját meghatározó, egyszersmind szemantikai alapmintázatát alkotó alapkategóriák a modern társadalmat haladásként felfogó, differenciálódási elméletek, az Ész egyetemességébe vetett hit, a társadalom egészét átfogó instrumentális (cél-eszköz) racionalitás uralma, valamint az Európa-centrikusság (Karácsony, 2005, 58).

A modernizmus racionalitásra, egyetemes érvényre és Európa-centrikusságra felesküdött kánonjának sajátos kvintesszenciáját adja például Max Weber munkássága is. Ố a társadalomtudományok egyik úttörô, könyvtárnyi (vita-)irodalmat ihletố, A protestáns etika és a kapitalizmus sæelleme (1982, 7-25) címú múvében arra a telített kérdésre keresi a választ, „hogy a körülmények miféle láncolata vezetett oda, hogy éppen a Nyugat talaján, és csakis itt keletkeztek olyan múvelődéstörténeti jelenségek, amelyek - legalábbis úgy véljük egyetemes jelentôségú és érvényú fejlődés irányába mutattak. Csak a Nyugaton létezik »tudomány«azon a fejlődési fokon, amelyet ma »érvényesnek «tartunk.”

${ }^{1}$ Kibertér: A szó a számítógépes tudományok diszciplínájának azon belül az internet világának viszonylag új keletú szakszava. A kifejezés a tudományos-fantasztikus irodalomból ment át a köztudatba, ahol olyan virtuális világot is jelent(het), amelyben a megszállott számítógép használók és más lények, például kiborgok élnek. A szó (kibernetika + tér) W. Gibson regényéból átvett sciencefiction kifejezés, mely a számítógép-kommunikáció birodalmát, annak virtuális világát kívánja megnevezni, amelyben elektronikus adatok tárolódnak és online adatforgalom, valamint kommunikáció zajlik. William Gibson tudományos-fantasztikus (sci-fi) szerzô Burning Chrome (1982) címú novellájában és Neurománc (1984) címú regényében alkotta meg a kifejezést. Ugyancsak Gibsontól származik a meatspace (a. m. hús-tér) kifejezés is, amelyet a kibertér ellentéteként használ a fizikai világ jelölésére (Kommunikációtudományi Nyitott Enciklopédia). 
A technológia társadalmi hatásainak propagandisztikus-mitikus összefüggéseivel foglalkozó francia filozófus-teológus Jacques Ellul $(1964,25)$ szerint a jelen nyugati civilizációjának átfogó jellemzóje a technika, amelyet a következóképpen határoz meg: ,a racionálisan elért (és a fejlődés egy adott fokán) abszolút hatékonysággal rendelkezó módszerek összessége az emberi tevékenység minden vonatkozásában."

Eliza Culea (2012) szerint egyes modernista elméleti perspektívák hihetetlenül jól felépített nézó- és elemzôpontjai egy-egy helyzetnek, amelyek a mai napig továbbélnek különbözó formában azon módszerekben, ahogy a világot értelmezzük és kategorizáljuk. Az emberi alkotás összes területére gyakorolt, döntó befolyásuk máig nem vesztette érvényét, beleértve azon módszereket is, melyekkel infrastruktúráinkat létrehoztuk, otthonainkat berendeztük vagy életünket általában strukturáljuk. Jellemzóik - lett légyen szó erôsségekról, hagyatékról vagy gyengeségekról - kiindulópontul szolgálhatnak a kibertér tulajdonságainak a történelmi elốzmények tágabb kontextusában történố megvitatásához.

A Newcastle-i Egyetem oktatói, Stephen Graham és Simon Marvin (1996) nyomdokain haladva következzen négy fóbb kategória, amelyek mentén megközelítjük a témát. Az egyik oldalon az utópianizmust és a technológiai determinizmust találjuk, melyek a társadalmat és a technológiát különálló, kölcsönhatásban nem álló entitásoknak tekintik, a másik oldalon pedig a társadalmi konstruktivizmust és a politikai gazdaságtan(-kritiká)t, amelyek egy határozottan összefonódó olvasatot nyújtanak. Maga a szerzópáros egy mérsékelt társadalmi konstruktivizmuson nyugvó módszerre esküszik, színezve azt némi politikai gazdaságtan elmélettel.

\section{Techno-utópianizmus}

A felvilágosodás korának gyermeke számára a technológia a társadalom megmentôje múltjának, jelenének és jövoójének gyermekbetegségeitól. Az utópianizmus optikai lencséjén keresztül tekintve az életünkre elementáris erôvel hatnak a technológia által generált „forradalmi változások.” E szellemáramlat két fóbb társadalomformáló módszert tulajdonít a technológiának, melynek dialektikus viszonya határozza meg és termeli újra a központi tanokat. Elôször is, adott egy reverzionista megközelítés, amely egy, a vidéki életformához való visszatérésre szólít fel a maga kézmúves és gazdálkodási ágazatok fenségére felesküdô, Lewis Mumfordnál $(1967,95)$ „demokratikus és decentralizált” szellemiségével. A második egy technofil életforma-központú felfogás, ahol a városiasodás egy mindinkább hangsúlyt kapó és koncentrált tapasztalat, amely egy folyamatosan éró állapot (Culea, 2012).

Noha a revizionista álláspont gyakran elốtérbe került az iparosodásnak a felkészületlen városokra gyakorolt kártékony hatásaira adott erôteljes válaszul a 19. században, a második világháborút követốen életre hívott külvárosok formájában tovább virágozva, megállapítható, hogy a technofil városi érdek uralja a 20. századot.

Egy techno-utópia egy olyan, a közelebbi vagy távolabbi jövóben játszódó, hipotetikus, ideális társadalom, amelyben a fejlett tudomány és technológia ideális életszínvonalat tesz le-

${ }^{2}$ A technika nem csak a technológiai modalitásokat írja le, de a jelenkor társadalmi, politikai és gazdasági szervezôdésének természetét is. A felvilágosodástól származtatott racionalizmus, funkcionalizmus és szekularitás jelöli ki a technika körvonalait (Karim, 2002). 
hetôvé, egyebek mellett megszüntetve a szúkösségét, a szenvedést, megváltoztatva az emberi természetet, akár az örökéletet is elhozva, a jogszabályok, kormányzatok és társadalmi körülmények pedig kizárólag az állampolgárok javára és érdekében hatnak, illetve múködnek.

Az utópiák kibontakozása, kulturalizációja és esztétizálása összekapcsolódik a „munka átkának" ellentételezéseként életre keló, részint emlékekból, részint mítoszokból szốtt világképekkel egy olyan életról, aranykorról, , amelyben nincsen verseny és kegyetlen küzdelem, ahol szelídek a vadállatok, ahol az ember az embernek nem farkasa" (Mumford, 2000: 102), hovatovább helyt ad a gépek kultuszának is. ${ }^{3}$ Minthogy a „munka természetszerúleg átok,” nem csoda, hogy idônként az a képzet bont szárnyat, „hogy az élet legkívánatosabb formája az volna, ha búvös gépezetek vagy robotok az ember részvétele nélkül saját maguktól végeznének el minden szükséges múveletet.” Egyszóval innen az automata eszméje, amely a parancsnak engedelmeskedik, és elvégez minden munkát. Ez az álom a civilizáció egész történelmén végigkísért, száz meg száz tündérmese és népi mítosz varázsos változatában, amikor még meg sem fogalmazódott a modern jelszó: „szüntessen meg minden munkát az automatizáció” (2000, 103-104). ${ }^{4}$

Az utópista nézetek hosszú múltját jelzi, hogy Morus Tamás már 1516-ban ilyen címú munkával jelentkezett (De Optimo Reipublicae Statu deque Nova Insula Utopia, közismert és rövidebb nevén „Utópia”), ám az emberi viszonyok technológia-vonatkozású kulturális lenyomatai ennél frissebbek és idônként éppenséggel ellentétes irányúak - egy rémisztô, vagy csak részben vonzó világot írva le.

Ez az irodalmi jelenség a disztópia, melynek prototípusa, vagy legalább is elsô világszerte ismert múve feltételezhetóen Mary Shelley 1818-as Frankenstein c. múve. Következzen néhány további példa ezen irodalmi múfajra, melyek szintén egy, az utópiákétól gyökeresen eltérố értékbeállítódást jeleznek, lerántva a leplet azon gépi kultúráról, amely nem a munkásra és életére, hanem a termékre, a termelés rendszerére és az abból származó anyagi vagy pénzbeli nyereségre összpontosít, vagy éppenséggel magára az emberiségre és jövớjére jelent veszélyt.

Madách Imre Az ember tragédiájának (1862) XI. londoni színében egy italméró helyen az egyik munkás megjegyzi (igaz elsôsorban egzisztenciális okokból) társának, hogy „a gépek, mondom, ördög múvei...”. Babits (1930/1933) Elıa pilóta avagy a tökéletes társadalom címú antiutópisztikus regénye - mely „nem jóslat, hanem intés” - már a haditechnika által a világra szabadított, szakadatlan háborúk kilátástalan vérzivatarai közepette játszódik, ebben a disztópikus világban immár nók is teljesítenek katonai szolgálatot. Jóval azt megelơzóen, hogy az atombomba komor és gyászos „menetekel”-ként megjelent volna a történelem falán.

Kurt Vonnegut angol nyelven Player Piano (1952), magyar nyelven eredetileg éppen Utópia, végül Gépzongora (2013) címmel megjelent regénye, amely, mint arra a szerzố az Eló-

\footnotetext{
${ }^{3}$ Azon eljárásokról, melyek segítségével a technikát az utópia megvalósulásának kulcsaként tüntetik fel a 20. század közepén, bővebben 1. Ellul, Jacques: Propaganda: The formation of men’s attitudes. New York, Vintage Books, 1973.

${ }^{4}$ Ehhez az álomhoz nemegyszer az a másik kapcsolódott, amely az emberiséget még egy átoktól szerette volna megszabadítani, a szegénységtốl, amelynek járma a leigázott népek vállára került. A bôségszaru, az áldott föld álma, ahol egyetlen kézmozdulat ételek és javak kimeríthetetlen készletét teremti eló: más szóval korunk folytonosan bôvüulố újratermelésének infantilis mennyországa - és végterméke - a fogyasztói társadalom (Mumford, 2000, 104), amely a szabadidó eltöltésének legfontosabb tevékenységformájává a vásárlást avatja (Romsics, 1999, 436).
} 
szóban utalást tesz (2013: 9), „nem arról szól, ami van, hanem ami lehetne,” szintén felvázolja egy torz technológiai fejlődésen nyugvó, a Harmadik (számítógépek által megtestesített) Ipari Forradalom $(2013,31)$ nyomán eljövő, új világ kísérteties képét, amelyre az automatizálásnak az életminóséget károsító árnya vetül - szintén tematikailag illeszkedik ehhez az irányvonalhoz. A regény lázadó karaktere, aki egyben a Szellemköntös Társasága ellenálló mozgalom titkos feje is, Lasher tiszteletes mindezt úgy írja le, hogy: „(...) olyanok a gépek a lakosság legnagyobb része számára, mint a fehérek voltak az indiánok számára. Az emberek úgy találják, hogy mivel a gépek megváltoztatják a világot, mind több és több hajdani értékük veszíti értelmét. Az emberek választhatnak, hogy másodosztályú gépekké válnak maguk is, vagy pedig a gépek kiszolgálóivá” (Vonnegut, 1952/2013, 425). A főszereplô régi barátja, Ed Finnerty pedig egész pontosan az elektronikát azonosítja a technológia főfonákságaként, amikor parafrazálva egy evangéliumi igét, kijelenti, hogy „ha elektronika által élsz, elektronika által fogsz meghalni. Sic semper tyrannis" (Vonnegut, 1952/2013, 95).

A technika kérdése felmerül a marxizmus - e legambiciózusabb emberi kísérlet (Muravchik, 2014, 15), e visszatéró, szinte minden nemzedéket magával ragadó, utópisztikus eszme (Csíkszentmihályi, 2007, 176) - szövegkörnyezetében is. Úgy tartja, hogy a technikai fejlődés és az anyagi érdekek átalakulása során kavarodik fel az ideológia habja a felszínre, a Marxék által tévesen múlékony történelmi mozzanatként azonosított magántulajdon és különálló háztartás pedig egyebek mellett a gépek fejlődése által jelenik meg (Marx-Engels, 1973, 12). A történelem egy késóbbi szakaszában a tókések, beruházva a termelési folyamatba, forradalmasítják a technológiát, hogy versenyben maradjanak - és, hogy végül megdöntse uralmukat a proletárforradalom. E teleologikus nézőpont szerint „az emberiség történetét mindig az ipar és a csere történetével összefüggésben kell tanulmányozni” (MarxEngels, 1973, 13). ${ }^{5}$

\section{Technológiai determinizmus}

David Bell (2009) szavaival a technológia akarva akaratlanul is rátelepszik a társadalomra, a magánszemély kénytelen passzívan elviselni annak hatásait, egyetlen lehetséges válaszként alkalmazkodva ahhoz. Következóleg a deterministák világképében a technológiai változás összekapcsolódik az elkerülhetetlenséggel.

Azon kriticizmus ellenére, amely hangsúlyozza, hogy a technológiák ritkán semlegesek, elvontak vagy tisztán függetlenek, hanem azokat egy sor társadalmi, kulturális, politikai és közvetett tényezố befolyásolja, Bell (2009) rámutat, hogy a technológia elkerülhetet-

\footnotetext{
${ }^{5}$ A neomarxista koncepciót kidolgozó wallersteini (2010, 48-49) világrendszer-elméleti perspektíva szerint - amely nemcsak a történelem lineáris felfogásával, hanem a felvilágosodás haladás-koncepcióját visszatükrözố fejlődés-gondolattal is szakít - az erôsen iparosodott és városiasodott centrumországokat a tókeigényesség és a magas bérek mellett a csúcstechnológia termelési mintái is jellemzik.

A posztmarxista filozófus szerzópáros Michael Hardt és Antonio Negri (2000) szerint a pénz, a munkaerô és a javak mellett napjaink termelésének és cseréjének elsốdleges eleme maga a technológia is; a világot kormányzó, szuverén hatalom, a Birodalom, vagyis az irányítás új logikájának és struktúrájának globális rendje által a prioritások áttevốdnek a kommunikáló, a kooperáló és az affektív munka területeire.
} 
lenségének és irányítatlanságának mítoszaiban az emberi lakosság jelentốs hányada hisz. A technológiai determinizmus e hiedelemrendszere egyidôs az ipari forradalommal és a kezdetektól azt jelzi, hogy egész társadalmak vívódnak az olyan új múszaki alkalmatosságok, mint akár a vonat keltette áhítat és nyugtalanság között.

Mindezt tükrözi egyfelól Petófi elhíresült költeményének („Száz vasutat, ezeret!”) kitörố lelkesedése, másfelól Nagymaros város elöljáróinak zaklatott irata 1852-ból, amely „fenyegetô vészként” szemléli a vasút térnyerését, attól tartva, hogy a városon keresztül haladó mozdony kéményéból szálló szikrák tüzet okozhatnak (1852. MMKMA Múszakirajzalbum-gyújtemény RA-19).

A technika varázsát és fenyegetését egyszerre, dialektikus egységként érteni és értelmezni reméló társadalomtudós és technológiafilozófus Lewis Mumford (2000) okfejtése szerint a technika nem semleges alkotórésze a kultúrának és a civilizációnak, ${ }^{6}$ mint ahogy az organikusság értelmében semmi sem lehet az. Hasonul és alakít, társadalmi szerkezetet, gondolkodási és magatartásformákat tükröz, bátorít s hív életre vagy sorvaszt el. Mumford úgy véli, hogy technika alatt kizárólag szerszámokat és gépeket érteni reduktív, az szerinte egy egész rendszer a gyártástól a fenntartáson át a hatalomgyakorlásig, számos rejtett dimenzióval, melyek a történelmi fejlemények folytán túntek el szinte teljesen a szemünk elól.

E gondolatkörök eklatáns példája Békés Márton és Böcskei Balázs Ki! címú, termékeny, szociológiailag megragadható kérdésfelvetésekkel élő szépirodalmi múve, amely egyenesen arra a következtetésre jut, hogy „a [középkori] vásárteret leváltja a betonsztráda, azt pedig a széles sávú internet” $(2015,14)$; „a nyom nélküli áramlás csatornái - amelynek fơ képviselôje a média, meg az infokommunikáció és a nyilvántartás, ellenórzés, igazgatás számtalan elektronikus rendszere - strukturálják már a nagyvárost” (2015, 16-17). Végeredményben pedig ,a technológia áthatja az életet, a média eltünteti a testet. Az információ feloldja az anyagot” $(2015,18)$.

A digitális technológiáktól való idegenkedés és azok feltételezett hatalma miatti nyugtalanság, illetve az irántuk érzett, e cikk során a késóbbiekben bemutatott digitális utópista, új vallást idézô, ${ }^{7}$ hipnotizált ámulat lényegében egyazon modernista, technológiai

${ }^{6}$ Lélektani hatásairól Mumford (1967, 99-100) így ír: „A gépi kultúra a maga eredendóen szervilis formájában nem tartotta fenn (...) az életet gazdagító hajlamokat, nem a munkásra és életére, hanem a termékre, a termelés rendszerére és az abból származó anyagi vagy pénzbeli nyereségre központosított. Akár a munkafelügyeló korbácsa, akár a mai futószalag könyörtelen továbbhaladása tartja múködésben, az óriásgépezet (melyet a szerzố a munkaszervezés tökélyre vitt technikájának metaforájaként használ) múveletei a gyorsaság, az arctalanság, a szabványosítás és a mennyiség útját egyengetik. Hogy ez miként hatott a munkásra vagy a munkanap eltelte utáni életére, azzal a mechanizált múveletek irányítói nem törốdtek. E rendszer kényszerei a nyílt rabszolgaságnál alattomosabban múködtek, de mint a rabszolgaságban, végül is éppúgy lealacsonyították az ellenôrzóket, mint az általuk ellenốrzött munkaerót.”

${ }^{7}$ A globális információs társadalom szimbolikus konstrukciójáról, az ôsi eredetú, vallásos gyökerú mítoszok (tömeg)lélektani-spirituális hatalmából erốt merító jellegéról, illetve a számítógépes kommunikáció „transzcendens látványosságát” létrehozó társadalmi erốtérról a.m. a digitális médiának a vállalatok és kormányok általi, vallási színezetú világméretû́ propagálásáról, bóvebben 1. Karim, Harim H.: A kiber-utópia és a paradicsom mítosza: Jacques Ellul propagandakutatásainak alkalmazása az információs társadalom retorikájának elemzésére. Információs Társadalom, 2002/1. 
determinista érem két oldala. Posztulátumuk közös, ezt szemlélteti a Ki! címú könyv és annak társszerzóje, a technoszkepszis iránytúje által vezérelt Békés Márton (2014) történész is, aki úgy látja, hogy „életünkre ma a technológiai fejlődés (és nem mondjuk a vallás, a szociális igazságosság elve, új politikai eszmék, vagy a múvészet) fejti ki a legnagyobb hatást. A technológiai fejlődés egy-két évtizede szinte kizárólag az infokommunikációs eszközök és hálózatok kapacitásának bốvüléseként értelmezôdik. Ez a drámai változásokat generáló aktor mélyebb hatást fejt ki gazdasági szerkezetünkre, szociális kapcsolatainkra, kulturális viszonyainkra és lelki életünkre, mint gondolnánk." 8

\section{Társadalmi konstruktivizmus}

A társadalmi konstruktivizmus valójában az elôzó kategóriák által alkalmazott szigorú szétválasztás közvetlen kritikája, egyszersmind a technológiai determinizmus önjelölt „kijavítója” (Bell, 2009), amennyiben a technológiára és a kultúrára egymással összefonódott területekként tekint, sốt abból indul ki, hogy a technológia pusztán saját társadalmi kontextusának mellékterméke. A technológiai tárgyak alaksatát a társadalmi folyamatok eredményeként szemléli, mely akkor szilárdul meg, ha az azt befolyásoló, érdekelt társadalmi csoportok megállapodnak. Az alakítás és felhasználás múveletét elóidézố társadalmi folyamatok mikro-szintú elemzésére összpontosít, továbbá úgy véli, hogy annak teljes hatása az egyéni inputok összességéból tevốdik össze, alulról felfelé szervezôdve. Emellett jelentéktelen színben tünteti fel a tudománynak és az iparnak az új technológiák fejlôdésében játszott szerepét és biztosra veszi egy olyan kulturális háttér közrejátszását, amely kihat az egyén és a tárgy között lejátszódó kölcsönhatások típusaira.

Könyvében Maria Bakardjeval (2005) - lényegében egy technológiai determinista olvasatot konstituálva - megállapítja, hogy ezek a tárgyak nem ösztönöznek alkalmazkodásra és felfedezésre, tekintve, hogy sajátos, fekete dobozszerú tárgyak képében jelentkeznek, melyeket az adott formájukban fogad el az ember. Mindazonáltal a szerzó annyiban árnyalja álláspontját, hogy aláhúzza: bármennyire komolyan is próbálják a termelók „felhasználó-biztossá” tenni termékeiket, fennmarad azon „orvosolhatatlan kétértelmúség,” amely az eredetileg nekik szántakon túlmutató, különféle felhasználásokkal és jelentésekkel ruházza fel óket. Ennél fogva a felhasználó és a technológia közti viszony egy állandó konfigurációs és rekonfigurációs folyamat, amelyet Donna Haraway (2007) az állatok háziasításához hasonlít.

${ }^{8}$ A Ki! címú könyv teleologikus eszmefuttatása és víziói a technológia hatalmáról és az azt felváltó új korszak bekövetkeztének hajnalpírjáról - feltételezésem szerint - éppenséggel a digitális utópisták (vagy: infotech-optimisták, 2015, 70) malmait segíti friss vízhez; hiszen ironikusan ugyanazon képzeletbeli, technológiai determinista elgondoláson alapul, amelyek évtizedeken át utóbbiakat ihlette. Ennél fogva, ha úgy nézzük, egy tốról fakad például Clay Shirky, Stephen Coleman, Manuel Castells vagy újabban Barry Wellman nézeteivel. Miközben a szerzók joggal utasítják vissza azt a narratívát, az infokommunikációs eszközök és csatornák mindenütt jelenlevőségének, magától értetődőségének a.m. hatalmának a hirdetése és közvetítése éppenséggel magkát digitalis utópista diskurzust és annak „forradalmi változásokról” értekező, önbeteljesító jóslatait hordozó metanyelvezetét és frazeológiáját visszhangozza (Iványi, 2015a). 
A technológia szociokulturális konstrukciójára irányuló posztmodern figyelem a technológia felépítésének értelmezố, interpretív feltárása felé fordul, mely során a társadalmi összefüggések, a kulturális normarendszerek és a hatalom tudásra, tervezésre és termelésre gyakorolt befolyása kap hangsúlyos szerepet. A technológia maga is része a diskurzusnak, a társadalom objektumain keresztül teremti meg és újra önmagát. Az új technológia egyfelól lehetôséget nyújthat a társadalomirányítás, a termelési folyamat alján vagy perifériáján lévók számára, hogy ellenálljanak az uralomnak és a kontrollnak, különféle eszközökkel vonva ki magukat ezek béklyóiból. Ámde a technológiai fejlôdés a fokozódó kontroll lehetôségét is magában hordozza másfelól, ilyen összefüggésekre James William Carey (1989, 9) már a távíró példáján keresztül is rátapintott9

A francia filozófus és társadalomtudós Jean-François Lyotard merész következtetése szerint a mai információs és kommunikációs technológiák következményei totalitáriusnak tekintendók (hasonlóan a huszadik század fóbb, megbukott történelemfilozófiáihoz), amennyiben a kommunikációs technológia csatornáin áramló tudás sajátos szúrốn át érkezik, érvényre juttatva egy olyan logikát, amely elôírások egész rendszere mentén állapítja meg, hogy mi számít a „tudáshoz” tartozó „legitim” jelentésnek. „A tudás kérdése az informatika korában minden korábbinál inkább hatalmi kérdés (1993, 23).”

\section{Politikai gazdaságtan(-kritika) elmélete}

A marxista alapokon nyugvó, idôvel továbbfejlődő politikai gazdaságtan(-kritika) elmélete azt sugallja, hogy a társadalom és a technológia közötti viszonyokat a kapitalista termelési módok közvetítik, ennél fogva az óket meghatározó, mindenkori politikai, gazdasági és társadalmi viszonyoknak vannak alárendelve, arra a tényre alapozva, hogy a technológia soha nem semleges és általában ipari vagy vállalati érdekeknek megfelelóen fejlôdik. A társadalmi konstruktivizmus által alkalmazott mikro-szintú megközelítéssel ellentétben a politikai gazdaságtan(-kritika) a nagyméretú politikai-gazdasági szerkezetekre összpontosít, elôtérbe állítva a tókés, az egyéni és az intézményi tevékenységeket.

E negyedik irányzat a technológiai fejlődést a modernizmus eszméjének terjesztôjeként látja, minthogy az megerósíti az uralkodó struktúrákat, miközben emeli az életszínvonalat. A populáris kultúra technológiáról alkotott nézeteinek (vagy mítoszainak) például az úgynevezett kreatív társadalmi-gazdasági osztály (Florida, 2002) és az információs társadalom felemelkedése - keringését az elmúlt években úgy tekinti, mint egyfajta eszközt az új technológiai forradalmakat kezdeményezô, kezelő és azokból hasznot húzó kormányzatok, hadseregek és transznacionális vállalatok érdekeinek szolgálatában, a tóke új lehetôségeihez és forrásaihoz vezetô átrendezôdés során (Kroker és Weinstein, 1994).

\footnotetext{
${ }^{9}$ A francia filozófus és társadalomtudós Jean-François Lyotard merész következtetése szerint a mai információs és kommunikációs technológiák következményei totalitáriusnak tekintendók (hasonlóan a huszadik század fó́bb, megbukott történelemfilozófiáihoz), amennyiben a kommunikációs technológia csatornáin áramló tudás sajátos szúrón át érkezik, érvényre juttatva egy olyan logikát, amely elő́rások egész rendszere mentén állapítja meg, hogy mi számít a „tudáshoz” tartozó „legitim” jelentésnek. „A tudás kérdése az informatika korában minden korábbinál inkább hatalmi kérdés (1993: 23).”
} 
A kibertér hatásainak konkrét kontextusában a nézet egyes képviselói azt vallják, hogy éles hanyatlásnak indul a technológiai determinizmus gazdasági és szubsztanciális növekedése, amint a világháló mind a termelésnek, mind a fogyasztásnak a végsố színterévé válik (Culea, 2012).

Mások, például a második generációs marokkói marxista antropológus Miriyam Aouragh (2012) szerint pedig éppenséggel magán a világhálón jelentkeznek a legmarkánsabban a politikai gazdaság mechanizmusai, a. m. a leginkább szembetúnóek azon ipari vagy vállalati érdekek, melyek meghatározzák az internet fejlődési ívét, egyszersmind a digitális technológia általi online kommunikációt.

\section{Vita modern és posztmodern között}

Ezek a megközelítések modernista elméleti perspektívákba ágyazódnak és tevékeny részét képezik a ma diskurzusának. Kritikával illetik óket, amiért egy nagy, a tudást és társadalmat egyesíteni kívánó elbeszélés megteremtésén munkálkodnak.

Szembesülve ezzel, a posztmodern ${ }^{10}$ elméletek felhagynak az egyetemes nézópontok keresésével, és megkérdôjelezik a haladás üdvözléstanát, a Felvilágosodásnak azon krédóját, melynek értelmében a tudományos és technológiai progresszió folytonos gazdasági fejlódést és jólétet teremt.

Jean-François Lyotard (1993) a modernista elméleteknek éppen e tulajdonságától és a korábban említett, mindenre kiterjedő és egyetemes igazságokat hirdetô felfogásától int óva.

Lyotard a tudás helyét és jellegét vizsgálta a posztmodern társadalmi helyzetben, úgy látta, hogy a tudás, azon belül a tudományos típusú tudás kontextusában alapvetô változások figyelhetók meg. Mégpedig azért, mert ezen a területen élesen kirajzolódnak a modern és a posztmodern közötti kontrasztok. Korábban azt a tudományt nevezték modernnek, amely önmagát a saját státuszáról folyó legitimációs diskurzusra vonatkoztatta, éppen azért, hogy egy történetfilozófiát implikáló "nagy elbeszéléssel” legitimálódjon (ennek mintatípusa Hegel "Enciklopédiája”). Pontosabban világosan elkülönült a megalapozó (legitimáló) diskurzus, azaz a nagy elbeszélés, az összes többi (rész)diskurzustól. „A modernitásnak az az általános beállítódása, hogy a diskurzus feltételeit a feltételekról szóló diskurzusban határozza meg” (Lyotard, 1993, 67). A posztmodern tudásnak viszont az a sajátossága, hogy benne van az a diskurzus, ami a tudás érvényességének szabályairól folyik. Nem támaszkodik külsó mércét adó nagy elbeszélésre, sốt szkeptikus, bizalmatlan mindenféle nagy elbeszéléssel szemben. Éppen ezért a posztmodern tudományos diskurzus az önnön érvényessége érdekében nem hivatkozhat sem a (hegeli) szellem dialektikájára, sem arra, hogy hozzájárul az emberiség emancipációjához. Az univerzalitás helyébe a lokalitás, a partikularitás lépett (Karácsony, 2005, 63-64).

A fentebb bemutatott modernista teóriák alapjain bontakozik ki a kiber-utópianizmus diskurzusa és a szkeptikusokkal folytatott, élénk és nagyszabású vita is.

\footnotetext{
${ }^{10}$ Egyes vélekedések szerint a posztmodern, mint azt sikeres regényeivel Umberto Eco is példázza, inkább a szellemi beállítódásnak egy meghatározott típusa, nem pedig egy a modernséget meghaladó, vitatott megítélésú történelmi állapotot leíró fogalom (Karácsony, 2005, 65)
} 


\section{Kiber-utópianizmus és az azt övezó szkepszis}

A kiber-utópianizmus - vagyis az a meggyoózôdés, hogy a digitális technológiák és az általuk megvalósított online kommunikáció önmagukban egyenjogúsítanak, illetve az abba vetett hit, hogy a világháló inkább az elnyomottnak kedvez, mint az elnyomónak - szellemisége a kezdetektól kíséri az internetet, és már 1995-ben kritika tárgya volt (Wilson, 2003, 477). Tulajdonképpen Karim H. Karim szavaival „, digitális médiumokra úgy tekintenek, mint amelyek megadják a választ az emberiség problémáira és létrehozzák a tökéletes társadalmat” (Karim, 2002).

Bár a kibertér romantikus nézetének hitelét részben csorbította az ún. dotkomlufik kipukkadása, az internetre tekintố, utópista szemléletmód vissza-visszaköszön a kétezres években (Buckley - Clark, 2009, 312-315) is, különösen a lakosságnak egyes technokrata, például az ún. világhálós startup kezdeményezésekben érdekelt köreiben, ám mindenekelốtt az arab világban lejátszódó forradalmakkal összefüggésben (Iványi, 2014).

A digitális médiában rejlô esetleges „egyenlôsítơ” potenciálról, az információ és a befolyás monopolisztikus, állami és/vagy gazdasági forrásaitól való függetlenítô hatásairól, valamint a hiteltelenné váló tömegkommunikációs eszközöket felváltó, alternatív szerepéról többen (például Denis McQuail, Russell W. Neuman vagy Stephen Coleman) írtak az elmúlt években. Sok elemzố véli úgy, hogy az új médiakörnyezet arra szolgál, hogy bevonja, tájékoztassa és felhatalmazza a nyilvánosságot; általa az ember bekapcsolódhat a közügyekbe, mégpedig jobban, mint azt a „régi” média teszi. Mindez gyakran a legmerészebb spekulációkhoz vezetett a kommunikáció új formáinak társadalmi hatásait illetốen: a Harper Magazin 1995-ben a számítógépes hálózati technológiák újításait egyenesen a túz megszelídítésének „,eget rengetô” hatásaihoz hasonlította (Iványi, 2015b).

Az amerikai médiateoretikus Douglas Rushkoff (2002, 26-28) szintén „dicshimnuszt zeng” a Web 2.0-ról, megállapítva, hogy „a világháló azon képessége, hogy az emberi lényeket hálózatba fogja, egyben az éltetốereje. Elôsegíti a kommunikációt, az együttmúködést, az osztozást, a segítókészséget és a közösséget... a világszerte a weboldalakon vitorlát bontó ötletek, információ és alkalmazások kihasználják azt az átláthatóságot, használhatóságot és hozzáférhetôséget, melyeknek az elhozatalára az internet a világra jött.”

A kiber-utópista tendenciák szempontjából meghatározó úgynevezett kaliforniai ideológia - amelynek eszmerendszeri elófutárai között van, aki az orosz-amerikai objektivista filozófus Ayn Randet véli felfedezni - egy, a hatvanas évek ellenkultúrájában gyökerezó bohém életmódot és a tekintélyelvúség-ellenes attitúdöket a techno-utópizmussal és a neoliberális gazdasági politikák támogatásával társító hitrendszer. Ezek a hittételek jellemzik azt a kultúrát, amelynek „ôsrobbanása” a Szilikon-völgy informatikaiparában és az Egyesült Államok nyugati partján ment végbe a kilencvenes évek derekán (Barbrook - Cameron, 2000). ${ }^{11}$

\footnotetext{
${ }^{11}$ A politikai gazdaságtan(-kritika) megközelítés ezen a helyen vetné fel, hogy talán e diskurzus dominanciája kialakulásának (gazdasági) háttere és a tény, hogy az Egyesült Allamok nyugati partján székel többek között a Twitter és az Instagram, az innen szintén nem messze fekvő Szilícium-völgyben pedig mások mellett az Apple, a Google, a Facebook, a Yahoo, az eBay, a Cisco, és a HewlettPackard is (Békés - Böcskei, 2015, 32), között bizonyára szoros az összefüggés. A Szilícium-völgy szóban forgó nagyvállalatai hivatalos kommunikációjuk szerint „meg akarják változtatni a világot,” „jobb hellyé akarják tenni,” „lehetôségeket adnak az embereknek,” és „,segítenek kapcsolatot tartani” stb. Állandó agitációjuk szerint az innovációban és a technológiai fejlốdésben hisznek, amely automatikusan ,jobbá teszi a világot” (Békés - Böcskei, 2015, 71).
} 
Végsố soron a techno-utópianizmus ezen formája annak hiedelmét tükrözi, hogy a technológiai változás forradalmasítja az emberi viszonyokat, illetve, hogy különösen a digitális technológia - amelynek a világháló egy szembetúnô elófutára - növelné a személyi szabadságot azáltal, hogy kiszabadítja az egyént a leviatán állam - vagy más hatalmi tényezốk - fojtogató szorításából. „Az önmagát felhatalmazó tudásmunkások nélkülözhetôvé teszik a hagyományos hierarchiáját; a digitális kommunikáció pedig lehetôvé teszi, hogy elkerüljék a modern várost, az ipari korszak ezen ósdi maradványát" - csendülnek fel az üdvrivalgás hangjai (Barbrook- Cameron, 2000).

A nézet zászlaja alatt gyülekezók azt állítják, hogy a digitális technológia meghaladta a hagyományos tengerentúli jobb/bal politikai elkülönülést, általa a politika elavulttá vált. Mindenesetre a techno-utópianizmus aránytalanul vonzza a politikai spektrum libertariánus jobbszélét. Ezen techno-utópista körök gyakran ellenségesen viszonyulnak az állami szabályozáshoz és a szabadpiaci rendszer fenségét éltetik (v.ö. Barbrook - Cameron, 2000).

Az elmúlt években és évtizedekben többször is felszínre jutottak kritikus fenntartások a digitális technológiák pozitivista olvasataival szemben. A brit-amerikai szerzó Andrew Keen (2006) azon a véleményen van, hogy a Web 2.0 egy nagy utópisztikus mozgalom, amely a marxi kommunista társadalomhoz hasonló.

„[A világháló] isteníti a kreatív amatốrt: az autodidakta filmrendezốt, a kollégista szobazenészt, a kiadatlan írót. Azt sugallja, hogy mindenki - bárha a legkevésbé múvelt és legérthetetlenebb is közülünk - használhatja és használnia is kell a digitális médiát, hogy megvalósíthassa önmagát. A Web 2.0 »felerôsíti « a kreativitásunkat, »demokratizálja « a médiát, »kiegyenlíti a pályát « szakértốk és amatôrök között. A Web 2.0 ellensége az »elitista « a hagyományos médiának" (Keen, 2006).

A kiber-utópisták krédója értelmében az internet azért játszhat fontos szerepet a politikai események alakításában, mert - a hagyományos médiumuktól, például a televíziótól eltérốen - nem egyirányú tömegkommunikációs eszköz, és nem csak két személy között teszi lehetôvé a párbeszédet, mint a telefon, hanem lehetôséget ad arra, hogy egész közösségek kommunikáljanak más közösségekkel - sokan sokakkal, ha úgy tetszik. Ennek pedig egyértelmú politikai és társadalmi vonzatai vannak. Clay Shirky (2011) az internetnek a média világára gyakorolt hatásait tekintve három fontos tényezốt emel ki:

- $\quad$ elôször is az internetnek hála az emberek rengeteg információhoz férhetnek hozzá;

- $\quad$ másodszor: a hétköznapi emberek lehetôséget kapnak általa arra, hogy véleményüket nyíltan hangoztassák;

- $\quad$ harmadszor: segítségével csoportok szervezhetik tevékenységüket.

Shirky (2011) közgazdaságtanból kölcsönzött metaforája szerint a szóban forgó digitális hálózatok nyomán egy masszív pozitív kínálati sokk érte az információ árát és terjedését, a nyilvános beszéd hatótávolságát, és a csoport-koordináció sebességét és arányát. Ahogy a kommunikációs tájkép egyre sưrúbbé, összetettebbé és részvételivé válik, a „behálózott" lakosság egyre több információhoz fér hozzá és több lehetôsége nyílik a nyilvános párbeszédben való részvételre. Elismeri az információhoz való hozzáférés fontosságát, emellett szerinte nem érdemes alábecsülni az „egymáshoz való hozzáférés” jelentôségét sem: azt, hogy hétköznapi emberek alakíthatják a közvéleményt, s csoportok koordinálhatják tevékenységüket az Interneten keresztül. A digitális technológia lehetôvé teszi a 
korábban szétszórt közösségek számára, hogy szinkronizálják véleményeiket, koordinálják lépéseiket, és hogy dokumentálják az eseményeket (Shirky, 2011).

Sokan vitatják azt, hogy a digitális technológiák és az általuk megvalósuló online kommunikáció számottevố hatással lennének a politikai folyamatok alakulására, ad absurdum az állampolgári részvétel elómozdítására. Legtöbbször azzal szoktak érvelni a szkeptikusok, hogy ezek az alkalmazások és oldalak, mint eszközök önmagukban hatástalanok, másodsorban pedig hozzá szokták tenni, hogy azok legalább annyit ártanak az egyenjogúsításnak és demokratizálódásnak, mint amennyire hasznára vannak, mivel az elnyomó kormányok is egyre ügyesebben használják azokat az eltérố vélemények elnyomására. Evgeny Morozov 2011-ben The Net Delusion: The Dark Side of Internet Freedom címmel megjelent könyve a kiber-utópizmus erôteljes kritikája. Elismerve, hogy korábban a szerzó maga is a kiber-utópista felfogás híve volt, azt jóhiszemúként és makacsként írja le az arra való képtelensége miatt, hogy felismerje a világháló árnyoldalát, nevezetesen a benne rejló, a kibertér tekintélyelvú megfigyelését és ellenôrzését lehetôvé tevő potenciál miatt (Morozov, 2011).

Magam is úgy vélem, hogy a digitális technológiák tulajdonságainak tárgyszerú megítéléséhez nélkülözhetetlen látnunk, hogy azok miként kereszteznek más társadalmi tényezóket (Iványi, 2015b). A korábban már idézett Aouragh (2012) is azon véleményen van, hogy ugyan a világhálóban rejlő potenciál fontos, ám annak folyamatait mindig meghatározzák a kibertér és a valóság eróviszonyai, vagyis: a nemzetközi globális nagyvállalatnak minôsüloó online szolgáltatók profitorientált „szolgálatkészsége” a cenzúra és a propaganda, valamint a megfigyelés reáliái.

A kibertér szkeptikusainak - idetartozik Malcolm Gladwell (2010) kanadai szociológus is - egy már fentebb említett, további érve a szóban forgó digitális technikák hatástalanságával függ össze. Nevezetesen, hogy nem teszik lehetóvé, hogy a máskülönben el nem kötelezett csoportok hatékony politikai cselekvókké váljanak. Gladwell véleménye szerint az emberek egy része olyan tevékenységgel próbál társadalmi változást elérni, amely kevés áldozatot követel, például a „Darfúr megmentésére” létrehozott (Save Darfur) Facebook-csoporthoz való csatlakozással, amelynek nincs igazi gyakorlati haszna.

Békés és Böcskei $(2015,81)$ szintén kétségbe vonja az új hálózati technológiákban rejló mozgósítási potenciált, sajátos „álaktivizmusról” beszélnek, sốt, szerintük az éppenséggel a politikai cselekvés vége: „a Facebook új cselekvési etikát foganatosított: tüntetésre hív, tüntetésról képet töltet fel. Azonnali bejelentkezés. Olyan, mintha te is ott lennél. Nem kell megmozdulni, nem kell kiállni, hiszen ott vagyok. Látod és hallod a szónokot. Te is bólogatsz. Nem mész ki. Nincs utcai vonulás, nincs spontán elszabadulás, nincs felállás, nincs spontán elszabadulás, nincs felállás, nincs rendốrsorfal, nincs beavatkozás. Nincs politikai cselekvés. Csak fényképezhetố tüntetés. A Facebook- és Tumblr-politika depolitizáltság, depolitizált jelenlét (...) A politika és a politikai cselekvés elválik az erôtól, a spontaneitástól, a kockakótól."”

Shirky (2011) szerint ezzel szemben a digitális technológiák azt ugyanakkor lehetôvé teszik, hogy az eredendóen elkötelezett csoportok új szabályok szerint játsszanak.

Malcolm Gladwell (2010) hangot ad a hálózati alapú számítógépes technológiák egyenjogúsító és közösségeket felerôsítő értékeit illetô kételyeinek. Bírálja Clay Shirkyt, amiért az ezekben az eszközökben rejló állítólagos forradalmi potenciált túlbecsüli és propagálja, azt a következtetést vonva le, hogy „Shirky az aktivizmusnak ezt a modelljét egy- 
fajta eloorelépésként értékeli. Azonban az pusztán egy olyan szervezési forma, amely elônyben részesíti a számunkra az információkhoz való hozzáférést biztosító gyenge közösségi összeköttetéseket azokkal az erôsebb kötelékekkel szemben, amelyek segítenek, hogy kitartsunk a ránk leselkedô veszély esetén.”

Shirky $(2009,190)$ arról érkezik, hogy „,a tranzakciós költségek csökkentésével a digitális [média]eszközök emelt felületet biztosítanak a gyakorlatias közösségek részére. Ezek a gyakorlatias közösségek eredendôen együttmúködőek, a közösségi [média] eszközök pedig gyönyörúen támogatják óket, hiszen éppen e közösségek tagjai képesek egymás toborzására, és arra, hogy az érdeklódő kutatók figyelmét felhívják magukra.”

Shirky megjegyzéseiból úgy túnik, igaza lehet a kultúrakutató Brett Neilsonnak, aki szerint a kiber-utópianizmus a posztmodern világ egyfajta világi vallásaként is felfogható (Neilson, 2004, 181).

Ugyanakkor a zsigeri feltételezés, hogy egyes társadalmi mozgalmak online jelenléttel eleve kudarcra vannak ítélve a leviatán állam világhálós kiterjedése miatt és/vagy hiteltelenek, mert hátterükben hatalmi-gazdasági érdekek munkálkodnak, pedig talán figyelmen kívül hagyja azon potenciált, amely elvileg talán tényleg lakozik bennük.

Véleményem szerint bizonyos fokig mind a kiber-utópista, mind a szkeptikus olvasat egy-egy, a posztmodern társadalmi valóságot leegyszerúsítố értelmezés.

\section{Irodalom}

Aouragh, Miriyam: Social media, mediation and the Arab revolutions. TripleC, 2012. Elérhetô: http://www.triple-c.at/index.php/tripleC/article/viewFile/416/399 (Letöltve: 2015. május 23.)

Bakardjieva, Maria: Internet Society: The Internet in Everyday Life. London: Sage, 2005.

Barbrook, Richard - Cameron, Andy: The Californian Ideology. In: Science as Culture 6.1 (1996), 4472. Elérhetô: http://www.imaginaryfutures.net/2007/04/17/the-californian-ideology-2/ (letöltve: 2015. március 31.)

Bell, David: Cyberculture Theorists: Manuel Castells and Donna Haraway. New York: Routledge, 2009.

Békés Márton - Böcskei Balázs: Ki! Budapest: L’Harmattan, 2015.

Buckley, Peter - Clark, Duncan: The Rough Guide to the Internet. London: Rough Guides Limited, 2009.

Csíkszentmihályi Mihály: A fejlódés útjai: a harmadik évezred pszichológiája. Budapest: Nyitott Könyvmúhely, 2007.

Culea, Eliza: Cyberculture Theory - Part 2: Quick Guide of Modernist Theoretical Approaches on Technology. December 17. DNarchi.

Ellul, Jacques: The technological society. New York: Vintage Books, 1964.

Ellul, Jacques: Propaganda: The formation of men's attitudes. New York: Vintage Books, 1973.

Florida, Richard: The Rise of the Creative Class: And How it's transforming work, leisure, community and everyday life. New York: Perseus Book Group, 2002.

Gladwell, Malcolm: Small Change. Why the revolution will not be tweeted. New Yorker. Elérhetô: http://www.newyorker.com/reporting/2010/10/04/101004fa_fact_gladwell (letöltve: 2015. május 25.)

Graham, Stephen - Simon Marvin: Telecommunications and the City: Electronic Spaces, Urban places. London: Routledge, 1996.

Haraway, Donna: When Species Meet. Minneapolis: University of Minnesota Press, 2007.

Hardt, Michael - Negri, Antonio: Empire. Cambridge: Harvard University Press, 2000. 
Iványi Márton: Világrendszer és világháló. Facebook-forradalom, mint orientalista belelátás? Jel-Kép, 2014/4. szám.

Iványi Márton: Holnap vs. Honlap. Békes Márton és Böcskei Balázs: Ki! címü könyvéról. Mandiner, 2015. Elérhetố: http://mandiner.hu/cikk/20150520_ivanyi_marton_holnap_vs_honlap_bekes_mar ton_es_bocskei_balazs_ki_cimu_konyverol (letöltve: 2015. május 23.)

Iványi Márton: Az online közösségi hálózatok és a véleménynyilvánítás pozitív és negatív szabadsága. Iskolakultúra, 2015/3. szám.

Karácsony Sándor: Filozófia - Társadalomelmélet. Budapest: Rejtjel, 2005

Karim, Harim H.: A kiber-utópia és a paradicsom mítosza: Jacques Ellul propagandakutatásainak alkalmazása az információs társadalom retorikájának elemzésére. Információs Társadalom, 2002/1.

Keen, Andrew: Web 2.0; The second generation of the Internet has arrived. It's worse than you think. Február 14. The Weekly Standard, 2006. Elérhetô: http://www.weeklystandard.com/Con tent/Public/Articles/000/000/006/714fjczq.asp (letöltve: 2015. március 31.)

Kroker, Arthur - Weinstein, Michael A.: Data Trash - The Theory of the Virtual Class. Montreal: New World Perspectives, 1994.

Lyotard, Jean-François: A posztmodern állapot. In: A posztmodern állapot, Jürgen Habermas, JeanFrançois Lyotard, Richard Rorty tanulmányai. Budapest: Századvég-Gond, 1993.

Marx, Karl - Engels, Friedrich: Feuerbach. A materialista és az idealista szemlélet ellentéte. Budapest: Kossuth, 1973.

Morozov, Evgeny: The Net Delusion. London: Penguin Group, 2011.

Mumford, Lewis: A gép mitosza. Budapest: Európa, 2000.

Muravchik, Joshua: Földre szállt mennyország. A szocializmus története. Budapest: Közép- és Kelet-Európai Történelem és Társadalom Kutatásáért Közalapítvány, 2014.

Neilson, Brett: Free Trade in the Bermuda Triangle. Minneapolis: University of Minnesota Press, 2004.

Romsics Ignác: Magyarország története a XX. században. Budapest: Osiris, 1999.

Rushkoff, Douglas: Renaissance Now! Media Ecology and the New Global Narrative. Hampton Press, 2002.

Shirky, Clay: Here Comes Everybody: The Power of Organizing Without Everybody. Penguin Books, 2009.

Shirky, Clay: The political power of social media. Technology, the Public Sphere and Political Change. Foreign Affairs. Elérhetô: http://www.foreignaffairs.com/articles/67038/clayshirky/the-political-power-of-social-media?page=show (letöltve: 2015. május 24.)

Vonnegut, Kurt: Gépzongora. Budapest: Helikon, 2013.

Weber, Max: A protestáns etika és a kapitalizmus szelleme. Vallásszociológiai írások. Budapest: Gondolat, 1982. Wilson, Stephen: Information Arts. Intersections of Art, Science, and Technology. Cambridge: MIT Press, 2003. 